\title{
STUDI PENERAPAN METODE ANALISIS DERIVATIF PADA DATA POTENSIAL GRAVITASI
}

\author{
Muhammad Amir Zain ${ }^{1 *}$, Muhammad Fahrur Rozi ${ }^{1)}$, Anisa Nur Septikasari ${ }^{1)}$, Muhammad \\ Nuruddianto $^{2)}$, Supriyanto ${ }^{1)}$, Ahmad Zarkasyi ${ }^{3)}$ \\ ${ }^{1)}$ Laboratorium Geofisika Modeling, Departemen Fisika, FMIPA, Kampus UI Depok, Jawa Barat, \\ 16424 \\ 2) Peminatan Geofisika, Departemen Fisika, FMIPA, Kampus UI Depok, Jawa Barat, 16424 \\ 3) Pusat Sumber Daya Geologi (PSDG), Jalan Soekarno Hatta No. 444, Bandung, Jawa Barat, 40254 \\ ${ }^{*}$ Email: zainnamir@ymail.com
}

\begin{abstract}
Abstrak
Dalam suatu eksplorasi panas bumi, metode geofisika merupakan satu diantara metode utama yang digunakan untuk mendeteksi keberadaan suatu sistem panas bumi. Keberadaan sistem panas bumi dapat diketahui dengan mencari struktur bawah permukaan bumi. Penelitian yang kami kerjakan bertujuan untuk mengidentifikasi struktur bawah permukaan bumi guna untuk mengetahui keberadaan sistem panas bumi. Metode yang akan kami pakai adalah satu diantara metode geofisika yang sering digunakan, yaitu metode gravitasi. Metode gravitasi merupakan metode yang didasarkan pada pengukuran variasi percepatan gravitasi di permukaan bumi. Metode ini mampu mendeteksi struktur geologi di bawah permukaan, seperti adanya struktur patahan, cekungan, graben, ataupun kaldera. Untuk memperjelas keberadaan struktur geologi di bawah permukaan tersebut, maka hasil dari pengolahan data metode gravitasi akan diolah lebih lanjut dengan analisis metode derivatif. Satu metode derivatif yang sering digunakan adalah metode gradien horisontal dan gradien vertikal orde dua. Kedua metode ini mampu mengetahui kontak vertikal antara bodi di bawah permukaan bumi serta dapat mengetahui jenis struktur patahan yang dihasilkan. Hasil akhir yang akan didapat berupa peta kontur anomali gradien horisontal dan peta kontur anomali gradien vertikal orde dua. Kemudian kedua peta ini akan dianalisis serta diintegrasikan dengan data geologi daerah penelitian.
\end{abstract}

\begin{abstract}
In geothermal exploration, geophysics method is one of main method which is used to detect the existence geothermal system. The existence of geothermal system can be known with searching earth subsurface structure. Our research goal is to identify subsurface structure that can be used to know geothermal system belong. The method that we used is gravity method. Gravity method is method based on gravity acceleration variation on earh surface. This method can detect subsurface geology structure such as fault, basin, graben, and caldera. To imaging subsurface structure geology more clearly, the result of gavity processing will be processed more advance with derivative analysis method. One of derivative metode that is often used, is horizontal gradient method and second order vertical method. Both of them can know vertical contact between subsurface body and know what kind of fault structure. The final result is anomaly horizontal gradient contour map and anomaly secong ordel vertical gradient map. And than both of map will be analyzed and integrated with gelogical data in field research.
\end{abstract}

Keywords: Gravity, stucture, gradient, fault

\section{Pendahuluan}

Sumber energi panas bumi merupakan sumber energi yang berasal dari batuan di bawah permukaan bumi yang sangat panas. Umumnya panas bumi berada pada daerah vulkanik dengan topografi yang tidak merata. Satu diantara metode geofisika yang sering dipakai dalam kegiatan eksplorasi panas bumi adalah metode gravitasi. Metode gravitasi digunakan untuk mendeteksi perbedaan densitas secara lateral pada batuan di bawah permukaan (Mussett dan Kham, 2000). Analis metode derivatif merupakan metode gravitasi yang dapat mengidentifikasi adanya sebuah struktur geologi bawah permukaan dengan jelas. Kedua metode ini mampu mengetahui kontak vertikal antara bodi di bawah permukaan bumi serta dapat mengetahui jenis struktur patahan yang dihasilkan.

\section{Metode Penelitian}

\subsection{Data dan Perangkat Penelitan}

Data yang akan digunakan merupakan data observasi gravitasi yang berasal dari Pusat Sumber Daya Geologi (PSDG), Bandung, Jawa Barat. Data yang penulis peroleh berupa data gravitasi relatif 
yang telah mengalami koreksi tidal di setiap titik pengukuran. Jumlah data yang penulis dapat sebanyak kurang lebih 282 data termasuk data base camp. Pengolahan data menggunakan perangkat lunak Microsoft excel dan Geosoft.

\subsection{Alir Pengolahan Data}

Pengolahan data awal gravitasi bertujuan untuk memperoleh nilai anomali bouguer lengkap dengan melakukan koreksi lintang, koreksi udara bebas, koreksi bouguer, dan koreksi medan terhadap nilai gravitasi absolut di setiap titiknya. Sebelumnya dilakukan perhitungan densitas batuan rata-rata untuk melakukan perhitungan pada koreksi bouguer dengan menggunakan metode parasnis. Hasil perhitungan nilai densitasnya sebesar $2.226 \mathrm{gr} / \mathrm{cm}^{3}$.

Tahap selanjutnya adalah melakukan pemisahan anomali bouguer lengkap karena pada data tersebut terdapat nilai anomali residual, anomali regional, serta noise sehingga harus dilakukan filterisasi untuk menghasilkan suatu peta kontur yang bersih dari noise. Hal pertama yang dilakukan adalah membuat power spectrum dengan menggunakan transformasi Fourier guna untuk mengubah domain ruang menjadi domain panjang gelombang (Blakely, 1995). Dari tahap tersebut diperoleh power spectrum yang akan terdiri dari zona regional, zona residual, dan noise. Untuk memisahkan zona-zoba tersebut digunakan butterworth filter dan bandpass filter dengan proses coba-coba (trial and error). Butterworth filter digunakan untuk memisahkan antara zona regional dan zona residual. Kemudian, bandpass filter digunakan untuk memotong sinyal noise yang masi terdapat pada zona residual.

Setelah mendapatkan peta kontur anomali regional dan anomali residual, maka dilakukan pengolahan data lanjutan. Sebenarnya melalui peta kontur anomali residual kita sudah dapat menginterpretasikan struktur geologi di bawah permukaan bumi. Namun diperlukan pengolahan lanjutan agar memperjelas keberadaan struktur geologi di bawah permukaan bumi dan hasil interpretasi data gravitasi memiliki kesesuaian dengan data geologi. Oleh karena itu, dilakukan penerapan metode gradien horisontal (horizontal gradient) untuk menentukan batas-batas kontras densitas dari data anomali residual. Batas-batas tersebut akan terlihat jelas ketika menggunakan metode ini. Sehingga metode ini dapat digunakan untuk meningkatkan resolusi dari bidang batas tersebut. Penerapan metode ini memakai persamaan sebagai berikut (Cordell and Grauch, 1985).

$$
H G=\sqrt{\left(\frac{\partial g}{\partial x}\right)^{2}+\left(\frac{\partial g}{\partial y}\right)^{2}}
$$

dimana $\left(\frac{\partial g}{\partial x}\right)$ dan $\left(\frac{\partial g}{\partial y}\right)$ merupakan turunan pertama horisontal gravitasi pada arah $x$ dan $y$ dengan satuan $\mathrm{mGal} / \mathrm{m}$.
Selain itu, dilakukan juga penerapan metode gradien vertikal orde dua (second vertical derivative) dengan cara menurunkan dua kali data gravitasi terhadap arah vertikal (Reynold, 1997).

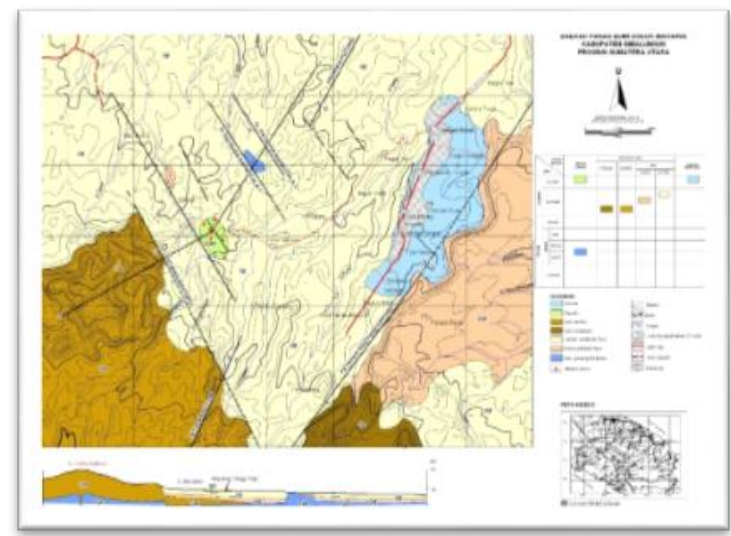

Gambar 1. Peta struktur geologi, geomorfologi, dan stratigrafi pada daerah penelitian (Pusat Sumber Daya Geologi, 2015)

$$
\frac{\partial^{2} g}{\partial z^{2}}=-\frac{\partial^{2} g}{\partial x^{2}}-\frac{\partial^{2} g}{\partial y^{2}}
$$

Metode ini berfungsi untuk memperjelas resolusi suatu peta kontur anomali agar semakin terlihat perbedaan nilai anomali yang dihasilkan serta dapat menentukan jenis patahan yang terlihat dengan cara mengambil garis slice sesuai dengan arah struktur patahan yang diinginkan.

\section{Hasil dan Pembahasan}

\subsection{Tinjauan Geologi Daerah Penelitian}

Dari hasil penelitian yang telah dilakukan sebelumnya oleh Pusat Sumber Daya Geologi (PSDG), 2006, keberadaan struktur geologi pada daerah penelitian dapat dilihat pada Gambar 1 .

Pada daerah penelitian ini terdapat beberapa struktur patahan, yaitu struktur patahan Sigayunggayung dan patahan Pulung memiliki struktur patahan berarah timur laut - barat daya. Kedua patahan tersebut memiliki arah $\mathrm{N} 40-60^{\circ} \mathrm{E}$ dengan kemiringan $>70^{\circ}$. Sedangkan pada arah barat laut tenggara terdapat tiga buah patahan, yaitu patahan Bahtopu yang memiliki arah memiliki arah N $320-$ $325^{\circ}$, serta patahan Bahbotala-1 dan patahan Bahbotala-2 yang memiliki arah N $320-325^{\circ} \mathrm{E}$.

Berdasarkan hasil pemetaan geologi daerah penelitian, maka telah berhasil ditemukan tujuh manifestasi panas bumi yang berupa mata air panas. Kenampakan gejala panas bumi ini berupa sumber mata air panas, fumarol dengan hembusan asap, kolam-kolam yang muncul dibeberapa lokasi serta menyebar di sekitar perbukitan Tinggi Raja pada batuan tufa Toba. 


\subsection{Interpretasi Hasil Penelitian}

Hasil pengolahan data gravitasi dapat dilihat pada Gambar 2, berupa peta kontur anomali bouguer lengkap.

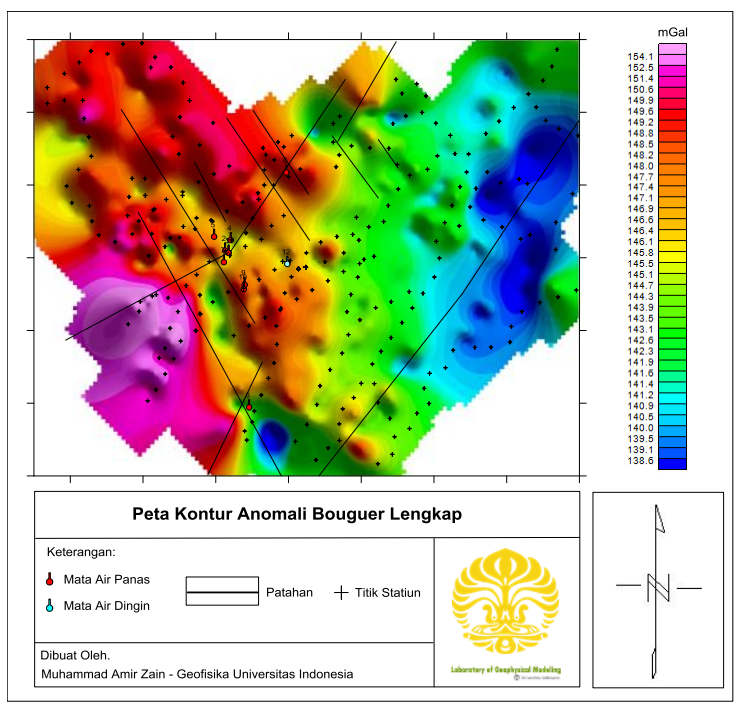

Gambar 2. Peta kontur anomali bouger lengkap.

Berdasarkan peta kontur anomali bouger lengkap dapat dilihat adanya respon nilai anomali gravitasi pada daerah penelitian berkitar $138 \mathrm{mGal}$ sampai $155 \mathrm{mGal}$. Pada bagian barat peta lebih didominasi nilai gravitasi tinggi, sedangkan dibagian timur peta lebih didominasi nilai gravitasi rendah. Nilai anomali gravitasi yang terlihat pada peta kontur anomali bouger lengkap sulit untuk menginterpretasi dimanakah letak struktur patahannya, hal ini dikarenakan masih terdapat nilai-nilai anomali regional, anomali residual, dan noise. Oleh karena itu, data struktur patahan geologi yang ada pada peta tersebut belum bisa terintegrasi dengan baik oleh data anomali bouger lengkap.

Selanjutnya, dalam penelitian kali ini dibuat peta kontur anomali residual yang merupakan hasil pemisahan peta kontur anomali bouguer lengkap. Pemisahan ini dilakukan dengan analisis filterisasi frekuensi utuk mengamati sumber anomali yang berkembang di daerah penelitian. Berikut adalah peta kontur anomali regional dan anomali residualnya.

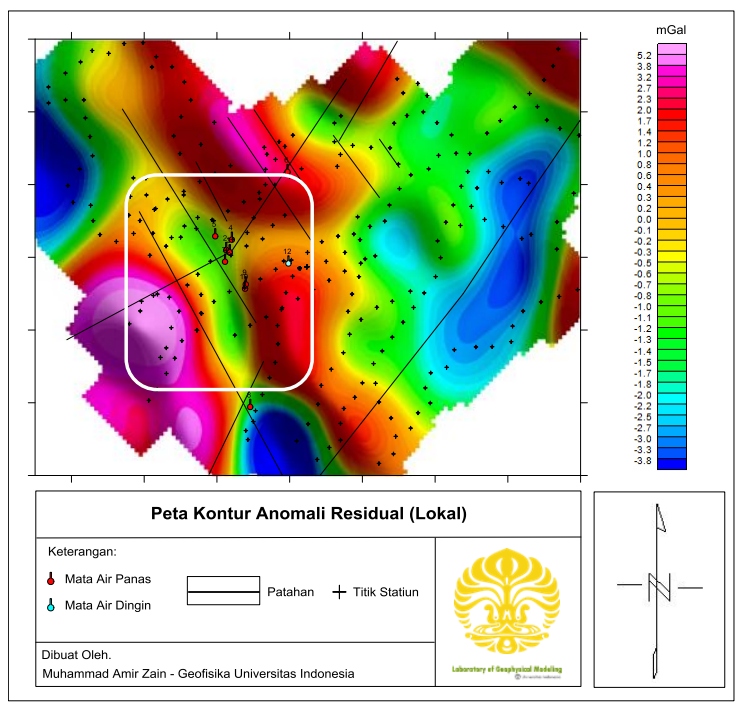

Gambar 3. Peta kontur anomali residual.

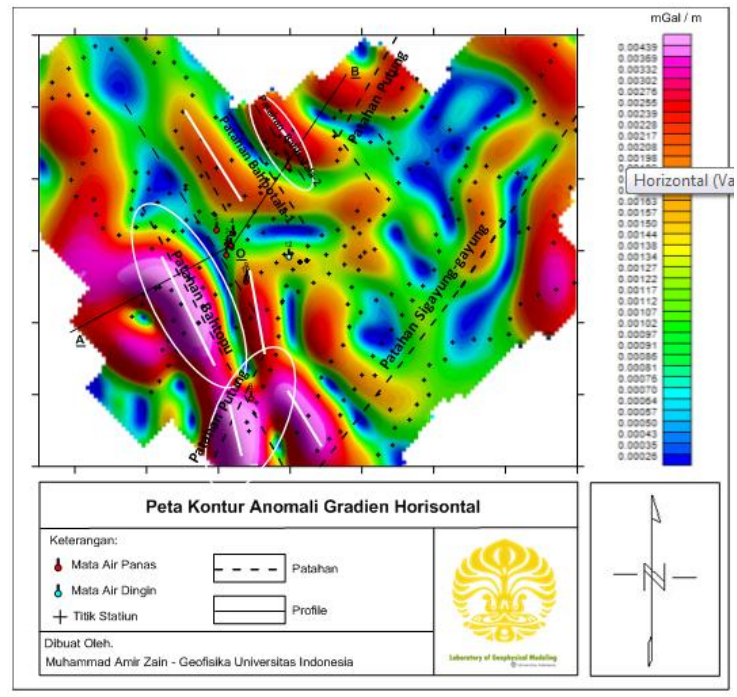

Gambar 4. Peta kontur anomali gradien horisontal.

Berdasarkan peta kontur anomali residual pada Gambar 3, terdapat sebuah graben yang ditunjukan oleh kotak berwarna putih. Disekitar daerah tersebut juga teridentifikasi adanya patahan yang sesuai dengan data struktur geologi. Selain itu, lokasi manifestasi juga teridentifikasi berada pada daerah graben. Hasil yang didapat dari peta kontur anomali residual mulai terintegrasi dengan baik oleh hasil data geologi daerah penelitian. Untuk dapat lebih meyakinkan dan mengetahui jenis patahan yang dihasilkan sesuai dengan informasi geologi atau tidak, maka kami akan menganalis peta kontur anomali residual ini dengan metode derivatif.

Selanjutnya dilakukan analisis secara terintegrasi. Analisis ini dilakukan dengan mencari korelasi antara hasil data geologi dengan hasil analisis metode derivatif sehingga diharapkan antara hasil data geologi dan data gravitasi terdapat korelasi yang tepat.

Dalam melakukan analisis secara terintegrasi, pertama dilakukan analisis gradien horisontal terhadap peta kontur anomali residual guna 
memperjelas keberadaan struktur geologi patahan. Pada Gambar 4, memperlihatkan peta kontur anomali gradien horisontal dengan variasi nilai antara $0.0001 \mathrm{mGal} / \mathrm{m}$ hingga $0.0170 \mathrm{mGal} / \mathrm{m}$. Nilai gradien horisontal rendah (berwarna biru) disebabkan karena tidak adanya perubahan nilai anomali residual, sedangkan nilai gradien horisontal tinggi disebabkan oleh perubahan nilai anomali residual secara signifikan.

Hasil interpretasi peta kontur anomali gradien horisontal dapat dilihat pada Gambar 4. Garis tebal berwarna putih merupakan hasil interpretasi adanya struktur geologi berupa patahan menurut data gravitasi yang telah dianalisis dengan metode gradien horisontal. Identifikasi ini dilihat pada peta lokasi yang memiliki nilai gradien horisontal yang tinggi. Setidaknya terdapat beberapa struktur patahan yang terdeteksi menurut data gravitasi. Apabila diintegrasikan dengan data geologi, maka hasil interpretasinya ditunjukan dengan lingkaran berwaran putih.

Terdapat setidaknya empat buah struktur patahan yang terintegrasi antara data geologi dan data gravitasi. Keempat patahan tersebut adalah struktur patahan di dekat patahan didekat patahan Bahtopu, patahan Bahbotala-1 dan Bahbotala-2, serta patahan Putung. Untuk daerah patahan Sigayung-gayung, belum terdeteksi oleh analisis metode gradien horisontal ini. Hal ini mungkin disebabkan kurang adanya data pengukuran tepat di lokasi patahan tersebut.

Kemudian langkah selanjutnya dalam melakukan analisis terintegrasi yaitu melakukan analisis metode gradien vertikal orde dua (second vertical derivative) untuk memastikan adanya keberadaan struktur geologi berupa patahan. Keberadaan struktur patahan pada metode ini dapat diidentifikasi dari adanya perubahan nilai gradien vertikal orde dua yang sangat kontras.

Keberadaan struktur geologi berupa patahan menurut peta kontur anomali gradien vertikal orde dua dapat dinterpretasikan berdasarkan hasil survei geologi (garis berwarna hitam), dimana ada beberapa patahan yang tepat berada diperbatasan antara nilai gradien vertikal orde dua yang tinggi dan rendah (Gambar 6). Namun demikian, masih ada beberapa nilai gradien vertikal orde dua yang belum terintegrasi dengan hasil survei geologi. Hal ini mungkin disebabkan terjadi karena tanda-tanda struktur patahan tidak terlihat di permukaan tanah.

Interpretasi hasil analisis gradien vertikal orde dua ditunjukan oleh garis berwarna putih, sedangkan hasil integrasi antara gradien vertikal orde dua dengan data hasil survei geologi ditunjukan dengan lingkaran berwarna putih (Gambar 5). Hal penting yang ditunjukan hasil integrasi ini adalah terdapatnya kecocokan beberapa data hasil gradien verikal orde dua dengan data hasil survei geologi,

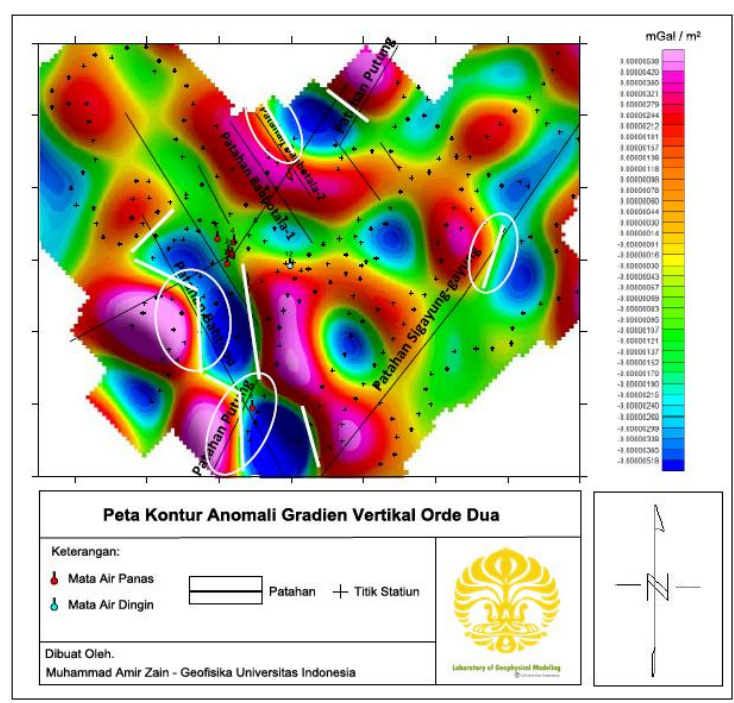

Gambar 5. Peta kontur anomali gradien vertikal orde dua.
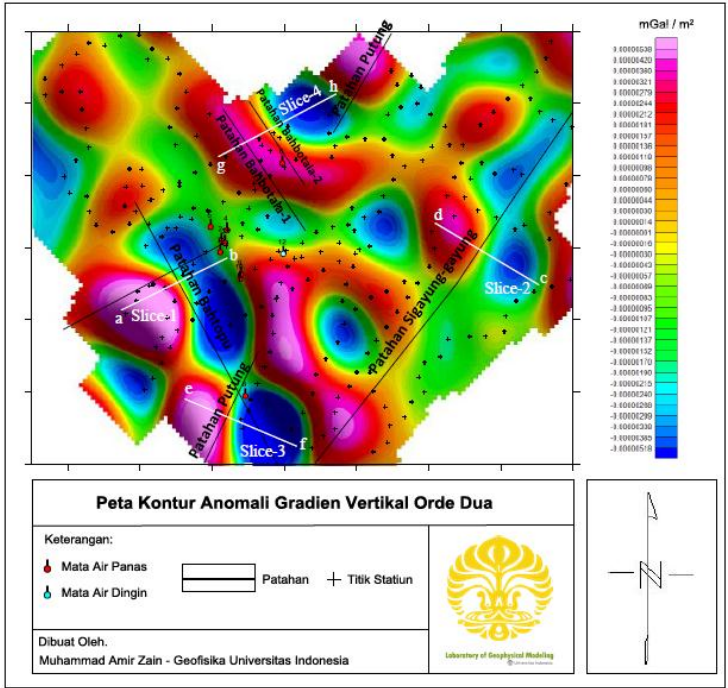

Gambar 6. Garis slice untuk mentukan jenis patahan berdasarkan peta kontur gradien vertikal orde dua..

meskipun letak patahannya tidak sama, tetapi masih dalam wilayah yang sama. Pada kedua data tersebut berhasil mengidentifikasi adanya sebuah struktur patahan didekat patahan Bahtopu, patahan Bahbotala-2, patahan Sigayung-gayung, serta patahan Putung dibagian barat daya peta. Sedangkan tida terdapat patahan di sekitar patahan Putung dibagian atas dan patahan Bahbotala-1, menurut hasil gradien vertikal orde dua. Letak patahan sesuai interpretasi gradien vertikal orde dua sedikit geser dari hasil geologinya. Untuk patahan Sigayung-gayung, hasil interpretasi gradien vertikal orde duanya hanya terletak di bagian atas patahan tersebut. Untuk bagian bawahnya, hasil gradien vertikal orde dua belum bisa mendeteksinya, meskipun sesuai data geologi terdapat patahan. Selain itu, pada daerah manifestasi berupa mata air panas, juga terdeteksi adanya patahan.

Analisis metode gradien vertikal orde dua ini dapat juga mengetahui jenis patahan yang dihasilkan, apakah termasuk patahan turun atau 
patahan naik. Jenis patahan ini dapat diketahui dengan mengambil data sesuai garis patahan yang ingin diketahui jenisnya (perhatikan Gambar 7 yang bergaris putih, garis ini merupakan slice dari beberapa patahan di dekat patahan Bahtopu, Sigayung-gayung, Bahbotala-2, dan Putung bagian barat daya).

Kemudian dibuat sebuah grafik sehingga nantinya akan menghasilkan nilai maksimum dan nilai minimum gradien vertikal orde dua. Nilai ini akan dibandingkan, apabila nilai maksimum lebih besar daripada nilai mutlak minimum, maka patahan yang terdeteksi merupakan patahan turun (normal) Jiaka nilai maksimum lebih kecil daripada nilai mutlak minimum maka termasuk kedalam patahan naik.
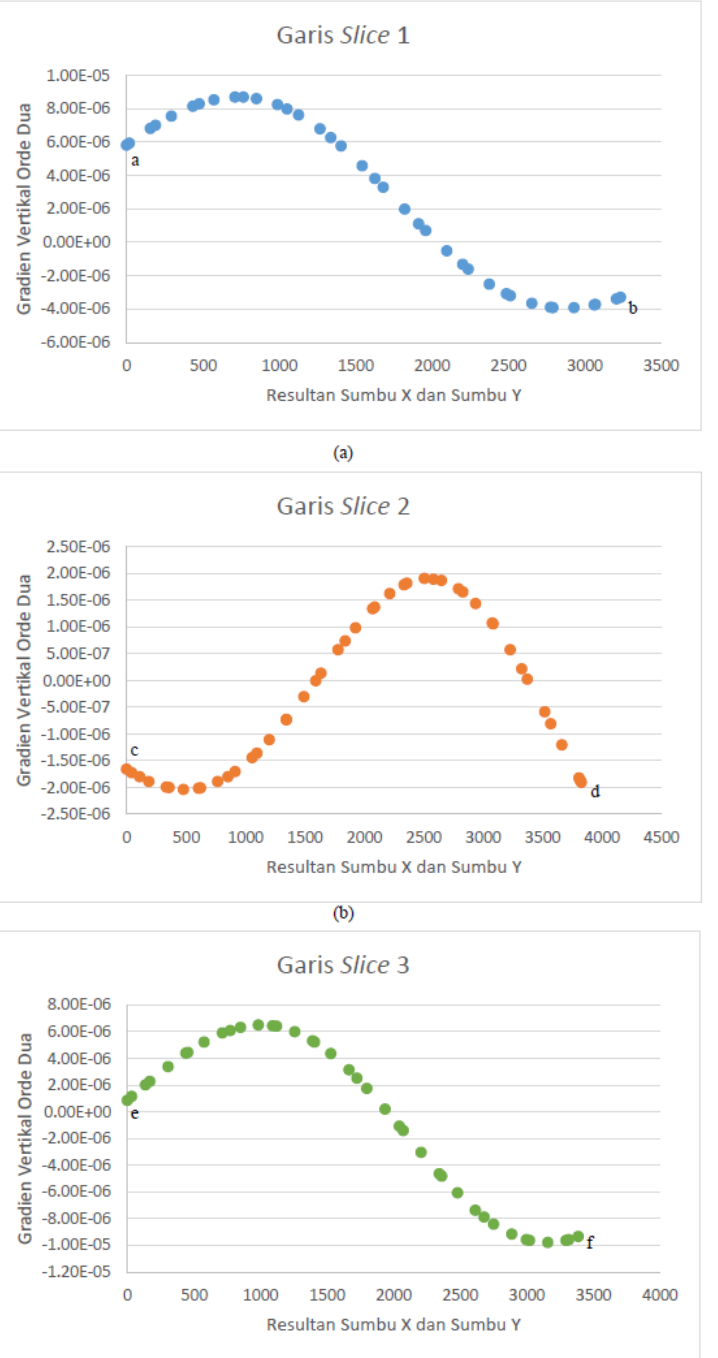

(c)

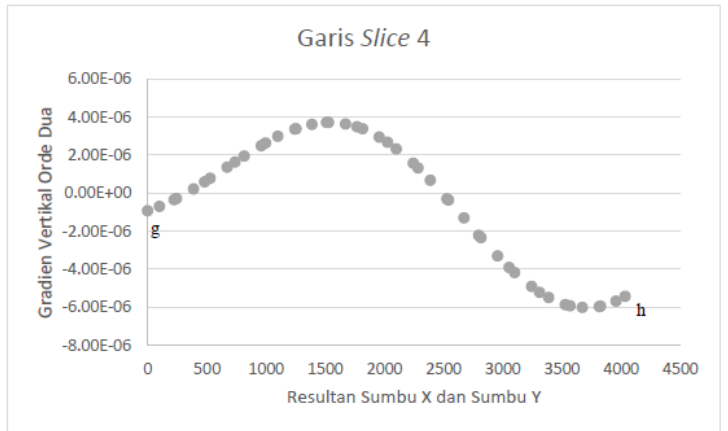

(d)

Gambar 7. Kurva hasil slice pada garis di dekat patahan (a) Bahtopu, (b) Sigayung-gayung, (c) Putung, dan (d) Bahbotala-2.

Dari hasil slice yang terlihat pada Gambar 7, maka untuk menentukan jenis patahannya, dapat dengan membandingkan antara nilai maksimum yang dihasilkan kurva dengan nilai minimum yang dihasilkan oleh kurva. Untuk hasil slice garis di dekat patahan Bahtopu teridentifikasi patahan normal, sedangkan untuk hasil slice di dekat patahan Sigayung-Gayung, Putung dan patahan Bahbotala-2 teridentifikasi patahan naik.

\section{Kesimpulan}

Kesimpulan yang dapat diambil dari pembahasan studi penerapan metode derivatif pada data potensial gravitasi adalah bahwa metode derivatif dapat dikatakan sebagai metode yang tepat untuk mengidentifikasi struktur patahan di bawah permukaan bumi.

Hasil yang diperoleh pada penelitian ini menunjukan hasil integrasi data yang baik antara data gravitasi dan data geologi. Selain itu, metode gradien vertikal orde dua mampu mengidentifikasi jenis patahan yang dihasilkan, yaitu berupa patahan normal untuk hasil slice di dekat patahan Bahtopu, dan patahan naik untuk hasil slice di dekat patahan Sigayung-gayung, patahan Putung, dan Patahan Bahbotala-2.

\section{Ucapan Terimakasih}

Terimakasih kepada pihak Pusat Sumber Daya Geologi (PSDG), Bandung, Jawa Barat, yang telah mengizinkan kami untuk memakai data gravitasi ini, selain itu terimakasih juga kepada dosen pembimbing, kepada teman-teman yang membantu dalam diskusi, dan lain-lain.

\section{Daftar Acuan}

[1] Blakely, R. J., The Second Vertical Derivative Method of Gravity Interpretation, Cambridge: Cambridge University Press (1996), p. 250251. 
[2] Cordell, L, and V. J. S. Grauch, Mapping Basement Magnetization Zones from Aeromagnetic Data in San Juan Basin, New Mexico, in Hinze (1985), W. J., Ed., The Utility of Regional Gravity and Magnetic Anomalt Maps, Sot. Explor. Geophysics. 181 \& 197.

[3] Musset, A. E., and M. A. Kham, Looking Into The Earth: Cambridge, Cambridge University Press (2000).

[4] Reynold, J., M., An Introduction to Applied and Environmental Geophysics, Chichester: John Wiley and Sons (1997).

[5] Dede Iim, Setiadarma D, Herry Sundhoro, Bangbang Sulaeman, Penyelidikan Geologi dan Geokimia di Daerah Pana Bumi Lapangan $X$, Proceeding Pemaparan Hasil Kegiatan Lapangan dan Non Lapangan, Bandung (2006), Pusat Sumber Daya Geologi. 